\title{
Trace-element behaviour in sediments of Ugandan part of Lake Victoria: results from sequential extraction and chemometrical evaluation
}

\author{
Nils Ribbe ${ }^{1,2} \cdot$ Kenneth Arinaitwe ${ }^{3} \cdot{\text { Tallent } \text { Dadi }^{4} \cdot \text { Kurt Friese }^{4} \cdot \text { Wolf von Tümpling }}^{1}$
}

Received: 6 August 2020 / Accepted: 8 March 2021 / Published online: 12 April 2021

(c) The Author(s) 2021

\begin{abstract}
Lake Victoria is the second largest freshwater lake and the largest tropical lake in the world. The transboundary lake has the fastest growing population in its catchment, which can impact the water and sediment quality. To determine the extent of anthropogenic effects on sediment quality in the Ugandan part of Lake Victoria, the contents and binding behaviour of trace elements were analysed, as well as organic matter and phosphorus in different sediment layers of both deep and coastal sediments near the coastal cities of Entebbe, Kampala and Jinja. The data were assessed using the German LAWA criteria for trace-element pollution, the Geo-Index, Cluster- and Factor analyses. Mostly, no critical trace-element contamination in the sediments of the investigated area was observed. However, changes in element distributions caused by anthropogenic influences from around the lake were detected, like higher contents of $\mathrm{Cu}, \mathrm{Ti}$ and $\mathrm{V}$ in near shore sediments with urban surrounding. Near Jinja, industrial wastewaters caused particularly elevated contents of $\mathrm{Cu}$ in the sediments $(70-121 \mathrm{mg} / \mathrm{kg}$, 3.5-6 times the geogenic background), exceeding the LAWA criteria and potentially harming the aquatic habitat. In addition, temporally growing organic matter contents in the lake sediments near the estuary of River Nzoia (from 4.2 to $17.6 \%$ in around 60 years) due to increased soil erosion in the river's catchment area and blooms of the water hyacinth became visible. This study demonstrates that the whole catchment area is responsible to ensure a healthy aquatic ecosystem in Lake Victoria.
\end{abstract}

Keywords Lake Victoria $\cdot$ Sediments $\cdot$ Trace elements and heavy metals $\cdot$ BCR extraction $\cdot I_{\text {geo }}$ and LAWA . Chemometrical judge- and assessment

\section{Introduction}

Trace-element contamination in lakes is a major concern especially in lakes still impacted by anthropogenic and population pressure. Despite being the largest freshwater lake,

Nils Ribbe

nils.ribbe@ufz.de

1 Central Laboratory for Water Analytics and Chemometrics, Helmholtz Centre for Environmental Research-UFZ, Brueckstrasse 3a, 39114 Magdeburg, Germany

2 Department of Inorganic and Analytical Chemistry, Friedrich Schiller University Jena, Lessingstraße 8, 07743 Jena, Germany

3 Department of Chemistry, Makerere University, P.O. Box 7062, Kampala, Uganda

4 Department of Lake Research, Helmholtz Centre for Environmental Research-UFZ, Brueckstrasse 3a, 39114 Magdeburg, Germany trace-element distribution in Lake Victoria sediments is not clearly understood due to limited studies mostly done on the Kenyan part of the Lake (Machiwa 2010; Outa et al. 2020). During the last 90 years, a strong population growth in the lake catchment area (growth rate of $3.5 \% / \mathrm{a}$ ) has led to a tenfold increase of the number of inhabitants in the catchment area which currently is approximately 40 million (Lake Victoria Basin Commission and GRID-Arendal 2017; Verschuren et al. 2002). The high population density around the lake (e.g. 549 inhabitants $/ \mathrm{km}^{2}$ in Kisumu County, Kenya (UNEP 2006) or 649 inhabitants $/ \mathrm{km}^{2}$ in Jinja District, Uganda (Uganda Bureau of Statistics 2016)) has an impact on the ecosystem's services of the lake. Besides a strong eutrophication of the lake, caused by a variety of multiple stressors (Hecky et al. 2010), an elevated input of trace elements is expected. Several factors contribute to that. First, growing cities and industries, together with immature wastewater treatment, led to an increased anthropogenic emission of trace elements and phosphorus (Oguttu et al. 2008). 
Second, progressing deforestation for wood production and agriculture in the catchment area of Lake Victoria intensified soil erosion (de la Paix et al. 2013). The consequence is an increased transportation of trace elements and nutrients through the rivers into the lake. Furthermore, mining activities (gold, iron, rare earth metals) contribute to the enhanced input of trace elements into lake (Ngure et al. 2014).

Above a certain concentration, trace elements have a toxic effect on the living organisms of aquatic ecosystems (Wong et al. 2000). Furthermore, they cannot be degraded biologically or chemically. However, a deposition of trace elements in the sediments is possible, enabling their immobilisation (Förstner 1985). Under certain circumstances, trace elements might be remobilised when converted back to a more mobile form (Duruibe et al. 2007; Peng et al. 2009). This process is strongly dependent on chemical conditions in the water body and the binding form of the trace element in the sediment (Jenne and Luoma 1975). Trace elements that are adsorbed on clay minerals are remobilised after an increase of the salinity. When precipitated as carbonates, they redissolve after a decrease of $\mathrm{pH}$. Trace elements adsorbed on Fe- and Mn-oxides and -hydroxides are remobilised under reducing conditions. Oxidising conditions trigger the remobilisation of trace elements precipitated as sulphide or being adsorbed on organic matter. Some binding forms just release the trace element under the influence of a strong acid, like aqua regia or perchloric acid, something that is unlikely under natural conditions. Being bound inside the crystal lattices of silicates, trace elements are solely remobilised by hydrofluoric acid (Rauret 1998). Clay-adsorbed, carbonate and Fe- and Mn-oxides and -hydroxide-adsorbed trace elements are considered to be bioavailable. The other binding forms thus are non-bioavailable (von Tümpling et al. 2013).

Thus, determining the trace elements binding form in addition to their total content is an easy way to enable risk evaluation of potential trace-element contamination. During the last decades, several analytical procedures have been developed to determine trace-element binding forms, so called sequential extraction procedures (Filgueiras et al. 2002). Throughout a sequential extraction, the sediment is extracted successively by different extraction agents, which specifically remobilise certain fractions. In case of the BCR sequential extraction procedure (developed by the Community Bureau of Reference, BCR), the sediments are subdivided into three fractions-namely the acid soluble, the reducible and the oxidizable fraction (Rauret et al. 2001).

The paper aims to provide a holistic view on the traceelement distribution on the Ugandan part of Lake Victoria. The focus of this paper is to investigate the influence of the distance to the shoreline as well as the sampling point's (SP) surroundings on trace element, phosphorus and organic matter distribution in sediments and the vertical distribution at each SP as well as the mobility of trace elements based on BCR extraction. This provides both insights into local differences and temporal developments of trace-element pollution into Lake Victoria. It is hypothesised that sediment trace-element contents decrease with increasing distance from the lake shoreline. It is also hypothesised that trace-element contents at shoreline depend on the land use type at the shoreline, e.g. differences between urban, rural or agricultural areas, respectively. Furthermore, it is expected that parts of the trace-element contents in the sediments are bioavailably bound.

\section{Materials and methods}

\section{Study site}

Lake Victoria, with a surface area of $68,870 \mathrm{~km}^{2}$ is the second largest freshwater lake and the largest tropical lake in the world. The transboundary is located in East Africa and covers parts of Tanzania (49\%), Uganda (45\%) and Kenya (6\%) with its catchment area extending over Burundi and Rwanda. The largest inflow, the River Kagera, arises at the Rwandan/Burundian border and enters Lake Victoria in Uganda. The only outflow of the lake is located at its northern shore near the city of Jinja, Uganda (Kayombo and Jorgensen 2005).

The sediment sampling took place in the Ugandan waters of Lake Victoria on seven different sampling points. Both, coastal (sampling points 1 and 4-7) as well as remote areas with a water depth of up to $68 \mathrm{~m}$ at sampling point (SP) 2 and SP 3 (Table 1; Fig. 1) were investigated.

\section{Sampling}

Sampling was carried out in May 2019. Undisturbed sediment cores were retrieved from each sampling point using a modified Kajak gravity corer (UWITEC, Austria) and plastic tubes of $60 \mathrm{~cm}$ length with an inner diameter of $9 \mathrm{~cm}$. From each SP, the upper $15 \mathrm{~cm}$ of sediments was taken and subdivided into three subsamples with a thickness of $5 \mathrm{~cm}$ each. Only the subsamples $0-5$ and $10-15 \mathrm{~cm}$ (X_00-05 and $X \_10-15$; $X$ : placeholder for SP; numbers represent the sediment layer in $\mathrm{cm}$ ) were analysed, with the exception of subsample 7_05-10 near Jinja. In addition, three more sediment cores were retrieved from sampling points 1,3 and 4 up to a depth of $38 \mathrm{~cm}$, sliced in $1 \mathrm{~cm}$ layers for the first 6 steps and $2 \mathrm{~cm}$ layers for the following steps, from top to bottom. The lowermost $6 \mathrm{~cm}$ were used for analyses, since they deliver the furthest look back into the past. All samples were filled in plastic bags, carefully closed and cooled. After 
Table 1 Coordinates, water depth and shore distance from the investigated sampling points

\begin{tabular}{lllll}
\hline SP & Location & Coordinates & $\begin{array}{l}\text { Water depth } \\
(\mathrm{m})\end{array}$ & $\begin{array}{l}\text { Distance } \\
\text { from shore } \\
(\mathrm{m})^{\mathrm{a}}\end{array}$ \\
\hline 1 & $\begin{array}{c}\text { Near estuaries of rivers } \\
\text { Nzoia and Sio }\end{array}$ & $00^{\circ} 09.613^{\prime} \mathrm{N}, 033^{\circ} 54.670^{\prime} \mathrm{E}$ & 9.8 & $1.85 \mathrm{~km}$ \\
& & & \\
2 & Deep waters & $00^{\circ} 00.040^{\prime} \mathrm{S}, 033^{\circ} 26.107^{\prime} \mathrm{E}$ & 40 & $20.55 \mathrm{~km}$ \\
3 & Deep waters & $00^{\circ} 30.438^{\prime} \mathrm{S}, 033^{\circ} 15.599^{\prime} \mathrm{E}$ & 68 & $73.37 \mathrm{~km}$ \\
4 & Murchison Bay & $00^{\circ} 03.375^{\prime} \mathrm{N}, 032^{\circ} 38.300^{\prime} \mathrm{E}$ & 20 & $3.65 \mathrm{~km}$ \\
5 & Buvoma Channel & $00^{\circ} 24.459^{\prime} \mathrm{N}, 033^{\circ} 14.239^{\prime} \mathrm{E}$ & 15 & $4.50 \mathrm{~km}$ \\
6 & Buvoma Channel & $00^{\circ} 14.827^{\prime} \mathrm{N}, 033^{\circ} 11.641^{\prime} \mathrm{E}$ & 25 & $3.75 \mathrm{~km}$ \\
7 & Jinja & $00^{\circ} 18.002^{\prime} \mathrm{N}, 033^{\circ} 13.282^{\prime} \mathrm{E}$ & 25 & $0.98 \mathrm{~km}$ \\
\hline
\end{tabular}

${ }^{\mathrm{a}}$ Google, n.d.
Fig. 1 Map of the sampling points, located in the northeastern part of Lake Victoria (Google, n.d.)

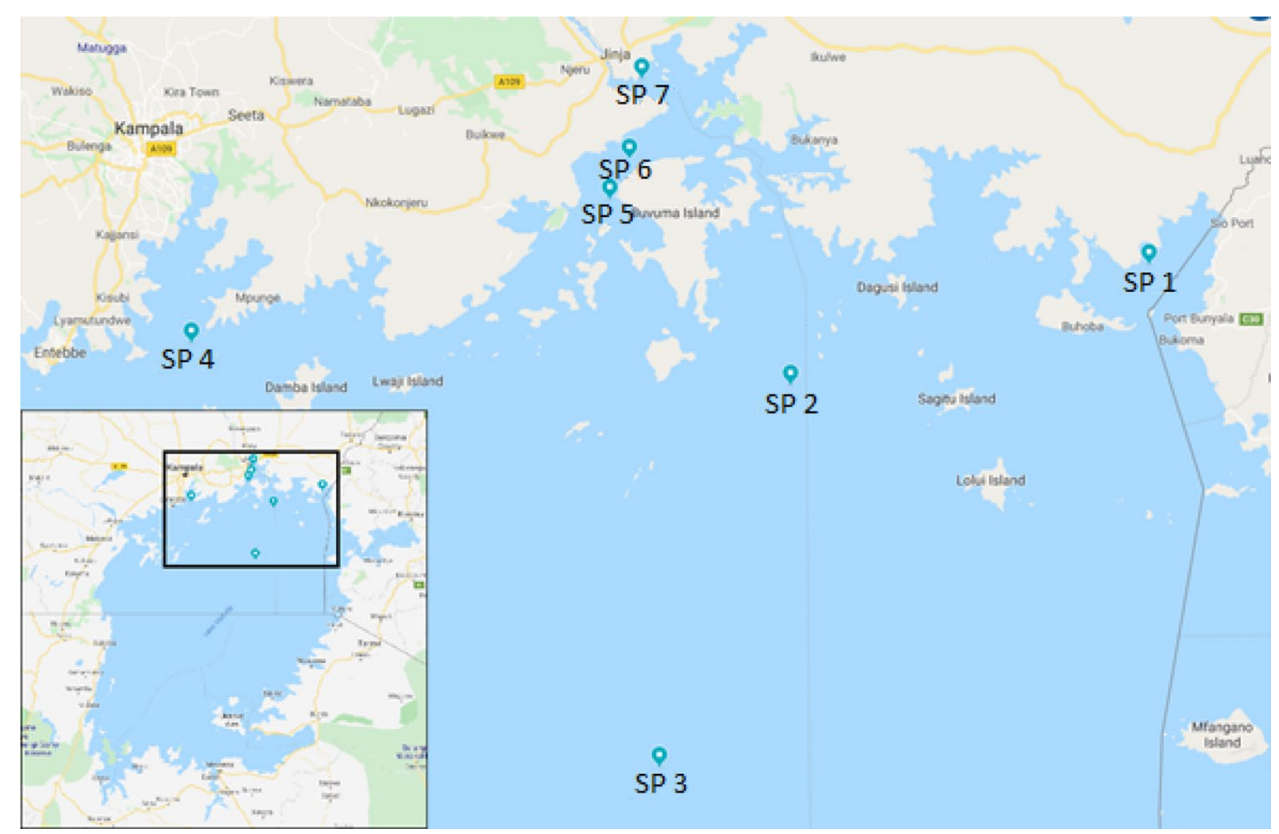

bringing them to Germany, the samples were stored in a fridge at a temperature of $5{ }^{\circ} \mathrm{C}$ until further sample preparation and analysis.

\section{Measurements}

Sediment $\mathrm{pH}$ and redox potential was measured in the field immediately after slicing, using multi-parameter meter fitted with conventional $\mathrm{pH}$ and redox potential electrodes (WTW Multi3430, Germany), calibrated using standard $\mathrm{pH}$ and redox potential solutions. The results are listed in the supplementary information (Table S3). Loss on ignition (LOI) was determined by drying an aliquot of the sediment samples at $105{ }^{\circ} \mathrm{C}$ followed by combustion of the oven dried aliquot in a muffle oven at $550{ }^{\circ} \mathrm{C}$ for $2 \mathrm{~h}$ with pre- and post-muffling weighing of the samples. Since LOI can be used as a proxy for the amount of organic matter in the sediment, it is referred to as organic matter in the following as well. Total phosphorus (TP) was analysed photometrically (Skalar, Netherlands) after combustion at $550{ }^{\circ} \mathrm{C}$ for $2 \mathrm{~h}$ and boiling in $1 \mathrm{~N} \mathrm{HCl}$ for 15 min according to the German Norm EN ISO 6878:2004.

For the element analysis, an aliquot of the samples was air-dried for $48 \mathrm{~h}$ in a clean air (dust-free) laboratory before freeze-drying it for $72 \mathrm{~h}$ (CHRIST Delta 1-24 LSC, Germany). High-temperature drying would make the sediments unviable for the BCR extraction due to probable changes in the binding form of the elements.

The dry sediments were sieved with a sieving machine (Vibratory Sieve Shaker Analysette 3, Fritsch, Germany) and a $63-\mu \mathrm{m}$ mesh plastic sieve $\left(\right.$ Delrin $\left.^{\circledR}\right)$. The $\leq 63-\mu$ m sediment fraction was stored in sealable plastic containers at room temperature. $250 \mathrm{mg}$ of each of the 18 sieved sediment samples were digested in quartz vessels with $6-\mathrm{mL} 65 \% \mathrm{HNO}_{3}$ and 2-mL 37\% $\mathrm{HCl}$ ("reverse aqua regia"; Suprapur ${ }^{\circledR}$ grade, Merck, Germany). The digestion was done in a pressure- and 
temperature-controlled microwave (Discover ${ }^{\circledR}$ SP-D, CEM Corporation, USA) at the following settings: $T_{\operatorname{Max}} 170{ }^{\circ} \mathrm{C}$, $18.5 \mathrm{~min}$. Element determination within the final solution is called "pseudo-total concentration" since digestion by reverse aqua regia does not dissolve silicates. Furthermore, sequential extraction was conducted on every sample excluding sample 4_00-05 (due to small amount of sample), following the BCR protocol by Rauret et al. (2001) with a conclusive digestion determining the residual fraction.

All the reagents used for analysis were of analytical grade or higher. Element concentrations in the soil extracts and digested samples were measured by inductively coupled plasma mass spectrometry (ICP-MS; Agilent 8800 TripleQuadrupole, Agilent Technologies ${ }^{\circledR}$, USA) following the Norm for application of ICP-MS EN ISO 17294-2:2004. All the quantified elements are listed in the following: As, $\mathrm{Cd}, \mathrm{Cr}, \mathrm{Cu}, \mathrm{Ni}, \mathrm{Pb}, \mathrm{Zn}, \mathrm{Li}, \mathrm{Be}, \mathrm{Mg}, \mathrm{Al}, \mathrm{Ca}, \mathrm{Ti}, \mathrm{V}, \mathrm{Mn}, \mathrm{Fe}$, $\mathrm{Co}, \mathrm{Se}, \mathrm{Rb}, \mathrm{Sr}, \mathrm{Mo}, \mathrm{Sn}$ and $\mathrm{Ba}$.

As quality assurance measures, blanks (clean extraction agents) and certified reference materials (CRM; BCR 701 for BCR extraction and LGC6187 for digestion) were investigated at every step of the extraction process and at the digestion. In case of the sequential extraction, element recovery rates were between 87 and $121 \%$ and comparable to other values published in the literature (Margui et al. 2004; Tokahoglu and Kartal 2006). The results of the digestion of LGC6187 overall lay inside the 95\% confidence interval of the certified values. A more detailed list with the results of the quality assurance samples and its description can be found in Tables S1 and S2 in the supplementary information.

\section{Data analysis and evaluation}

The results of the BCR extraction were transformed to "summed contents" (SC; Eq. 1) and "fraction percentages" (FP; Eq. 2). The former serves verifying the BCR results by comparing the summed contents with the pseudo-total contents and the latter was used to extract information about the binding behaviour of the studied elements:

$$
\begin{aligned}
& \mathrm{SC}_{x}=\sum_{n=1}^{4} c_{n, x} \\
& \mathrm{FP}_{n, x}=\frac{c_{n, x}}{\mathrm{SC}_{x}}
\end{aligned}
$$

where SC is the summed content, FP is the fraction percentage, $n$ is the $n$th fraction, and $x$ is the element $x$.

To detect structures and correlations in the obtained dataset, cluster analyses were used, according to Ward's method with the squared Euclidean distance as distance measure. In addition, factor analyses were conducted (Varimax raw rotation). To verify the results of the statistical analyses, randomly chosen $10 \%$ of the dataset were each increased and decreased by $10 \%$. Besides small differences in factor scores and loadings, no changes in the main trends of the statistical analyses were observed, thus securing the validity of the statements being made from the findings towards random errors. Before the statistical analyses, all data were $z$-transformed for comparability between the various parameters. All statistical analyses and dendrograms were performed and drawn by Statistica (Version 13).

The results of the digestion were evaluated using the Geoindex $I_{\text {geo }}$ by Müller, which gives information about the local enrichment of an element in a certain sample (Müller 1979). Its local content is ranked depending on the geogenic background of the element. The higher the rank is, the higher the enrichment. In this study, the reference value (RV; reference for geogenic background) was set to its lowest element content out of all analysed samples. In addition, the criteria published by the German Working Group of the Federal States on Water Issues (LAWA) on heavy metal contamination of aquatic ecosystems helped evaluating the risks of aquatic ecosystem damage caused by some heavy metals $(\mathrm{Cd}, \mathrm{Cr}$, $\mathrm{Cu}, \mathrm{Ni}, \mathrm{Pb}$ and $\mathrm{Zn}$ ) (LAWA-working groups "Zielvorgaben" und "Qualitative Hydrologie von Fließgewässern" 1998). Besides, the metalloid arsenic was evaluated with values published by the ARGE ELBE (Krüger et al. 2000), due to its present potential of harming the aquatic ecosystem. In the following, the mentioned elements are referred to as "priority" trace elements and were looked at in more detail during evaluation.

\section{Results and discussion}

\section{Trace-element and nutrient contents}

The pseudo-total contents of the most relevant elements, having been declared as "priority" trace elements and exhibiting a risk to the aquatic ecosystem of Lake Victoria, of all samples are summarised in Table 2. In addition, 16 more elements were measured (see "Measurements"). The contents of the elements not listed in Table 2 are given in the supplementary information (Table S3). To evaluate the status of trace-element pollution in the Ugandan part of Lake Victoria, the presented results were compared with the results from most recently published studies of the other countries around the lake (see Table 2). The sediments from the Ugandan part of the lake contain less $\mathrm{Zn}$ and Cd compared to results from Kenyan and Tanzanian studies-maximum contents are below or close to the average of these studies. On the other hand, higher loads of $\mathrm{Cu}$ and $\mathrm{Cr}$ are noticeable in the investigated area. Since the element distribution differs between the sampling points, the differentiated element 
Table 2 Range and mean of the "priority" trace element $(\mathrm{mg} / \mathrm{kg})$ in sediments from this study (Uganda) and the most recently published studies of the Tanzanian and Kenyan part of Lake Victoria (Machiwa 2010; Outa et al. 2020)

\begin{tabular}{|c|c|c|c|c|c|c|c|c|c|}
\hline & \multicolumn{3}{|c|}{ Uganda (this study) $n=18$} & \multicolumn{3}{|c|}{$\begin{array}{l}\text { Tanzania (Machiwa 2010) } \\
n=20\end{array}$} & \multicolumn{3}{|c|}{$\begin{array}{l}\text { Kenya (Outa et al. 2020) } \\
n=147\end{array}$} \\
\hline & Range & Mean & Median & Range & Mean & Median & Range & Mean & Median $^{\mathrm{a}}$ \\
\hline As & $2.9-6.6$ & 4.7 & 4.7 & - & - & - & $1.2-6.2$ & 3.43 & - \\
\hline $\mathrm{Cd}$ & $0.06-0.26$ & 0.16 & 0.16 & $0.01-1.75$ & 0.74 & 0.7 & $0.09-0.57$ & 0.25 & - \\
\hline $\mathrm{Cr}$ & $29-100$ & 69 & 74 & $16.5-54.6$ & 29.3 & 29 & $26.7-56.9$ & 36.4 & - \\
\hline $\mathrm{Cu}$ & $21-121$ & 39 & 31 & ND-89.7 & 24.2 & 18.9 & $23.7-60.1$ & 37.7 & - \\
\hline $\mathrm{Ni}$ & $19-56$ & 29 & 27 & - & - & - & $15.9-29.0$ & 19.4 & - \\
\hline $\mathrm{Pb}$ & $10-25$ & 17 & 17 & ND-71.4 & 18.3 & 13.8 & $6.82-195$ & 51.7 & - \\
\hline $\mathrm{Zn}$ & $49-103$ & 71 & 72 & $1-294$ & 98.9 & 86.6 & $81.6-295$ & 137 & - \\
\hline
\end{tabular}

${ }^{\mathrm{a}}$ Not indicated
Table 3 "Priority" trace-element contents $(\mathrm{mg} / \mathrm{kg}$ ) of all 18 samples with Geo-index classifications in brackets (class 0: $1-1.5 \times \mathrm{RV}$; class 1: $1.5-3 \times \mathrm{RV}$; class 2: 3-6×RV; italics: $\mathrm{RV}$, bold: maximum value), target trace-element contents by LAWA ( ${ }^{\mathrm{a}} \mathrm{As}$ from Krüger et al. 2000) and information about LOI $(\%)$ and TP $(\mathrm{g} / \mathrm{kg})$

\begin{tabular}{|c|c|c|c|c|c|c|c|c|c|}
\hline Sample & As & Cd & $\mathrm{Cr}$ & $\mathrm{Cu}$ & $\mathbf{N i}$ & $\mathbf{P b}$ & $\mathbf{Z n}$ & LOI & TP \\
\hline $1 \_00-05$ & $3,2(0)$ & $0,06(0)$ & $59(1)$ & $26(0)$ & $36(1)$ & $10(0)$ & $58(0)$ & 17.6 & 1 \\
\hline $1 \_10-15$ & $2,9(0)$ & $0,07(0)$ & $70(1)$ & $28(0)$ & $39(1)$ & $11(0)$ & $71(0)$ & 15.9 & 0.4 \\
\hline $1 \_00-36$ & $4,5(1)$ & 0,12 (1) & $95(2)$ & $40(1)$ & $56(2)$ & $14(0)$ & $103(1)$ & 4.2 & 0.1 \\
\hline $2 \_00-05$ & $6,6(1)$ & 0,18 (1) & $46(1)$ & $32(0)$ & $26(0)$ & $18(1)$ & $81(1)$ & 37 & 2 \\
\hline $2 \_10-15$ & $5,7(1)$ & $0,22(2)$ & $64(1)$ & $32(1)$ & $29(1)$ & $18(1)$ & $89(1)$ & 36.3 & 2.7 \\
\hline $3 \_00-05$ & $3,7(0)$ & $0,25(2)$ & $39(0)$ & $21(0)$ & $24(0)$ & $14(0)$ & 77 (1) & 29.7 & 1.9 \\
\hline $3 \_10-15$ & $4,2(0)$ & 0,19 (2) & $34(0)$ & $23(0)$ & $22(0)$ & $14(0)$ & $73(0)$ & 27.2 & 1.3 \\
\hline $3 \_24-30$ & $3,0(0)$ & $0,26(2)$ & $29(0)$ & $21(0)$ & $19(0)$ & $12(0)$ & $79(1)$ & 22 & 3.8 \\
\hline $4 \_00-05$ & $6,5(1)$ & 0,15 (1) & $75(1)$ & $24(0)$ & $21(0)$ & $21(1)$ & $75(1)$ & 42.1 & 2.6 \\
\hline $4 \_10-15$ & $5,0(1)$ & 0,13 (1) & $75(1)$ & $26(0)$ & $21(0)$ & $16(0)$ & $59(0)$ & 42.2 & 1.4 \\
\hline $4 \_32-38$ & $4,1(0)$ & $0,14(1)$ & $74(1)$ & $28(0)$ & $19(0)$ & $14(0)$ & $54(0)$ & 42.8 & 1.2 \\
\hline $5 \_00-05$ & $4,8(1)$ & $0,18(1)$ & $77(1)$ & $31(0)$ & $24(0)$ & $20(1)$ & $61(0)$ & 43.6 & 2.3 \\
\hline $5 \_10-15$ & $5,3(1)$ & 0,19 (2) & $82(1)$ & $40(1)$ & $27(0)$ & $16(1)$ & $49(0)$ & 43.7 & 1.7 \\
\hline $6 \_00-05$ & $5,7(1)$ & $0,16(1)$ & $78(1)$ & $32(0)$ & $27(0)$ & $22(1)$ & $63(0)$ & 39.9 & 1.5 \\
\hline $6 \_10-15$ & $4,7(1)$ & $0,12(1)$ & $73(1)$ & $32(0)$ & $23(0)$ & $18(1)$ & $73(0)$ & 37.5 & 1.2 \\
\hline $7 \_00-05$ & $4,3(0)$ & $0,16(1)$ & $84(1)$ & $70(2)$ & $44(1)$ & $23(1)$ & $72(0)$ & 42.4 & 1.7 \\
\hline $7 \_05-10$ & $4,9(1)$ & $0,09(0)$ & $81(1)$ & $79(2)$ & $30(1)$ & $25(1)$ & $79(1)$ & 40.8 & 1.4 \\
\hline $7 \_10-15$ & $5,0(1)$ & $0,23(2)$ & $100(2)$ & $121(2)$ & $30(1)$ & $24(1)$ & $60(0)$ & 37.1 & 1.3 \\
\hline $\begin{array}{l}\text { Target by } \\
\text { LAWA }\end{array}$ & $20^{\mathrm{a}}$ & 1.2 & 200 & 60 & 50 & 100 & 200 & & \\
\hline legend & Class 0 & Class 1 & Class 2 & & & $\left(\mathrm{I}_{\mathrm{geo}}\right)$ & & & \\
\hline
\end{tabular}

contents of each of the studied samples are listed in Table 3. To facilitate the evaluation of the element contents, the $I_{\text {geo }}$ has been added to Table 3 . For reasons of clarity, the table was restricted to the "priority" trace elements. As mentioned before, a complete presentation of the results is given in Table S3.

It is clear, that SP 3 is the sampling point with lowest contents of trace elements (except for $\mathrm{Cd}$ ). This might be due to the maximum distance between SP 3 and the shore. Since direct input of trace elements from the shoreline has far less influence on the sediment composition in the deep waters, the $\mathrm{Cd}$ enrichment should have been caused by the geogenic variance of $\mathrm{Cd}$ distribution rather than anthropogenic influences. Sediment contamination seems to increase with decreasing distance to the shore. Sampling point 7 near Jinja is the sampling point closest to the shore having the 
strongest enrichment of "priority" trace elements. Besides an increased input of trace elements from general sources like urban runoff, this enrichment might originate from some industrial point sources. For example, the leather industry, situated in close distance to the lake, discharges considerable amounts of $\mathrm{Cr}$-contaminated wastewater into the lake (approximately $2 \mathrm{t} / \mathrm{a}$ ) (Oguttu et al. 2008). Until 1982, a Cu smelter was operated in Jinja (Kasese Municipality), causing a huge emission of $\mathrm{Cu}$ and other metals into the lake by directly discharging its effluents through the Masese wetland into Lake Victoria. $5940 \pm 56.2 \mathrm{mg} / \mathrm{kg}$ of $\mathrm{Cu}$ was found in the soil of the Masese wetland near the shore of Lake Victoria (Nabulo et al. 2008). Moreover, a waste dump was abandoned on the ground of the $\mathrm{Cu}$ smelter after its closure (Ugandan Radio Network 2009; NewVision 2013), still causing $\mathrm{Cu}$ concentrations of $357 \mathrm{mg} / \mathrm{L}$ in its effluents in 2008 (Nabulo et al. 2008) and thus prolonging the negative consequences for the environment in the region.

The amount of organic matter depends on the location of the sampling points as well. Whereas in remote areas (far away from the shore) the deposition of organic matter is mostly restricted to aquatic plants and organisms, it is strongly influenced by the degradation of the thin humus rich layer in soils in nearshore areas, as exemplified by the difference between LOI of SP 3 (and SP 2) and sampling points 4-7 (Piccolo 1996).

Sampling point 1 has a remarkably different sediment composition in comparison to the other sampling points. It has a very low LOI and TP, thus contrasting the established relation between LOI and the distance between the SP and the shore. The reason for that is most likely found in the surrounding area of the SP, where the estuaries of the rivers Sio and Nzoia (approximately $12 \mathrm{~km}$ distance to the sampling point) are located. The deposited riverine sediments seem to influence the sediment composition of SP 1 strongly, containing eroded soils from the river's catchment area. With a discharge of $170 \mathrm{~m}^{3} / \mathrm{s}$ (more than 20 times higher than river Sio), river Nzoia has the highest discharge of all Kenyan rivers entering Lake Victoria and should be the main contributor to the LOI (Okungu and Opango 2002). Sample 1_30-36 has much less LOI and TP than the overlying samples, thus indicating a temporal change in the condition of the river's catchment area leading to an altered composition of the riverine sediments entering Lake Victoria. The trace-element contents are affected by that as well, as seen by decreasing contents of $\mathrm{As}, \mathrm{Cr}, \mathrm{Cu}, \mathrm{Ni}$ and $\mathrm{Zn}$. With a suitable sedimentation rate, the studied samples can be assigned to a certain space of time. Since dating was not part of this study, the sedimentation rate determined by Ramlal et al. (2003) for the Buvuma Channel (near sampling points 5 and 6) was applied as an approximation $(0.67 \mathrm{~cm} / \mathrm{a})$. With that, the 5-cm-thick sediment layers are corresponding to 7.5 years and the earliest point described by sample 1_10-15 is near the end of the twentieth century. Accordingly, the sample 1_30-36 dates to the 1960s. Since the 1960s, the catchment area of river Nzoia has undergone significant changes concerning its land use, pictured by a significant increase in agricultural areas (from 39.6\% in 1973 to $64.3 \%$ in 2000-2001) and a decrease in forest areas, i.e. from $12.3 \%$ in 1973 to $7 \%$ in 2000-2001 (Githui et al. 2009). This resulted in enhanced runoff of rainwater and soil erosion, washing parts of the upper soil layer containing higher amounts of humus into the river, which explains the increase of LOI in the upper sediment layers of SP 1 (Githui et al. 2009). In addition, the population increase in the shore area of Lake Victoria, as for example in Budalangi was from 53,000 in 2001 (Onywere et al. 2007) to 66,500 in 2008 (Hongo et al. 2008), contributed to that as well. Formerly, the riverine sediments were most likely dominated by lithogenic ferralsols (Sombroek et al. 1980). The increased input of organic matter into the river might have diluted the lithogenic component, lowering the content of trace elements in the sediment. The decreased percentage of the lithogenic component is also indicated by shrinking $\mathrm{Fe}$ and $\mathrm{Al}$ contents in the samples of SP 1 (Table S3). It is noticeable, that both bulk elements do not decrease with the same ratio ( $-33 \%$ for $\mathrm{Al} ;-14 \%$ for $\mathrm{Fe}$ ), which might be due to their different sedimentation behaviour. Another source of organic matter could have been the bloom of the water hyacinth that happened around the end of the twentieth century in nearshore areas of Lake Victoria and effected the area around SP 1 as well (Wanda et al 2016). After the release of the Neochettina weevil in 2000-2001 (Ochiel and Njoka 2005), dead or bitten off plants could have sunk to the bottom and increased the organic carbon of the sediments. The lack of a major increase of LOI at the other sampling points might originate in municipal inputs of organic matter overshadowing the influence of the water hyacinth.

Regarding the other sampling points, no significant increase in trace-element contents is observable despite the long timescale displayed by the samples, apart from slightly elevated contents of $\mathrm{Zn}$ and $\mathrm{Pb}$ in sampling points 4 and 5 . This indicates the low human impact on trace-element pollution from the shore areas into Lake Victoria during the last decades. At SP 7, the decreasing impact of the closed $\mathrm{Cu}$ smelter is demonstrated. Over time, the contaminated soils and the waste dump probably released most of the remaining $\mathrm{Cu}$, reducing its input into Lake Victoria and causing smaller $\mathrm{Cu}$ contents in the upper sediment layers of the lake. However, as the LAWA criteria show, it still causes probable damage to the aquatic ecosystem exceeding the limit concentration for $\mathrm{Cu}$ contamination $(60 \mathrm{mg} / \mathrm{kg})$ in sample 7_00-05 $(75.6 \mathrm{mg} / \mathrm{kg})$. Apart from that, except for the Ni content in sample 1_30-36, the trace-element contamination of all 
sediments in the investigated area seems to be of no concern. However, since the high Ni content in sample 1_30-36 seems to be of lithogenic origin, the environment might have been adapted to it.

\section{Local differences in sediment composition}

To study the element pattern of the sampling points in more detail, a cluster analysis was done with the pseudo-total contents of all 23 elements, LOI and TP, grouping together samples with similar sediment composition. Two main groups become apparent (sampling points $1-3$ and sampling points 4-7, mismatch of sample 4_00-05), differing from the extent of urbanisation in their surroundings (Fig. 2). The SP 1 is located at a rural coastline and sampling points 2 and 3 are 20 respectively $70 \mathrm{~km}$, far away from the nearest shore. SP 4 in front of the Murchison Bay near Kampala and Entebbe, sampling points 5 and 6 in the Buvuma channel and SP 7 in front of Jinja are altogether exposed to a much bigger anthropogenic influence, which is described in more detail in the following and most likely causes the observable split in the cluster. Examples of the influence of Jinja on the lake's sediment composition have been mentioned already in the last part. The influence of Kampala on the trace-element content of surrounding wetlands and the Murchison Bay by the uncontrolled effluent of industrial and municipal wastewaters was reported several times in the past as well (Nabulo et al. 2008; Mbabazi et al. 2010; Fuhrimann et al. 2015). An extension of that influence beyond the Murchison Bay seems plausible. Sampling points 5 and 6 could be influenced by the settlement of Kiyindi with its ferry services to Buvuma Island. The high distance between SP 1 and sampling points 2 and 3 highlights the special status of SP 1, which is caused by the river sediments from rivers Nzoia and Sio, entering the lake nearby and migrating towards SP 1.

To understand the backgrounds of these results, a closer look on the element distribution was assessed. Thus, patterns might be identified causing the apparent split of the sampling points. Figure 3 a shows the dendrogram emerging from the cluster analysis of the element contents. Five groups of elements with differing patterns in their distribution among the 7 sampling points are evident. For each group, examples of those patterns are demonstrated in Fig. 3b-f. Group $1(\mathrm{Li}$, $\mathrm{Al}, \mathrm{Ni}, \mathrm{Co}$ ) demonstrates the mentioned influence of the estuaries of the rivers Nzoia and Sio on the sediment composition of SP 1, which is reflected by elevated contents of the associated elements in the sediments of SP 1 compared to the other sampling points. Another characteristic of the riverine influence on SP 1 are increasing contents of the associated elements in the deeper sediment layers. This phenomenon was traced back to a temporally increasing entry of organic matter probably resulting in a dilution of the trace elements in the upper sediment layer. The same course of element contents in SP 1 also applies to group 2 (Be, $\mathrm{Mg}$, $\mathrm{Rb}, \mathrm{Fe}, \mathrm{Zn}, \mathrm{Sn}$ ). However, other than in group 1, related elements show an enrichment in sampling points 2 and 3 as well. Mwamburi (2003) studied the sediment composition of river Nzoia. A comparison with his results should enable a verification of our finding that SP 1 is influenced by river sediments from river Nzoia. It is noticeable, that especially
Fig. 2 Cluster analysis of the element composition using Ward's method with the squared Euclidean distance and $z$-transformed concentration values

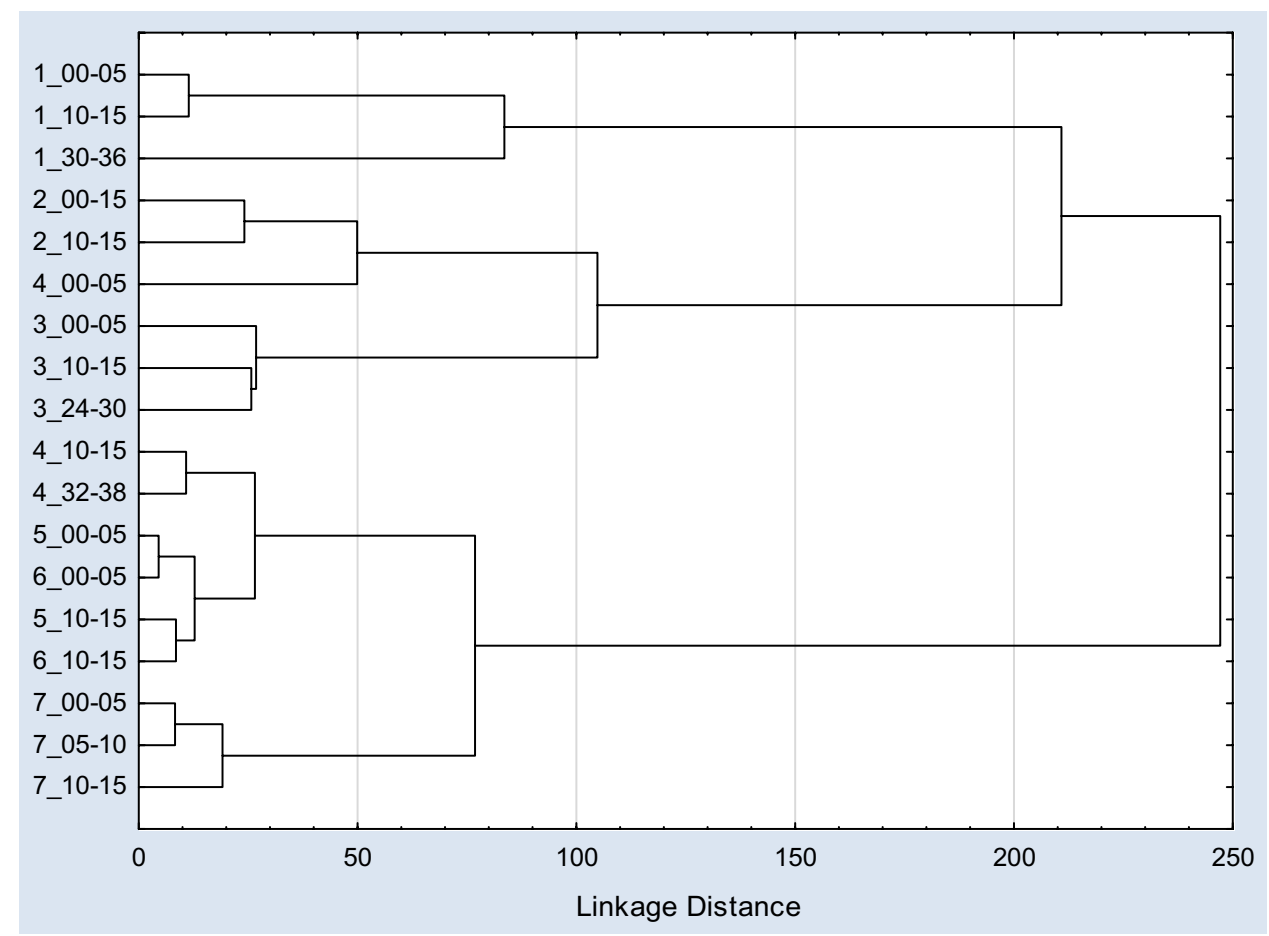




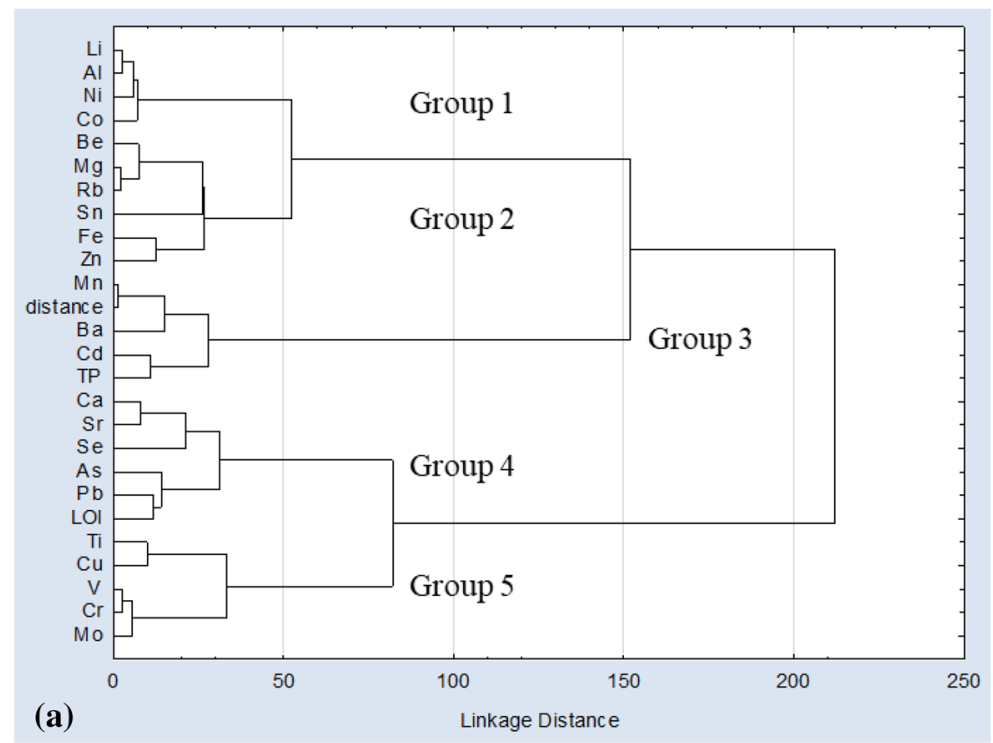

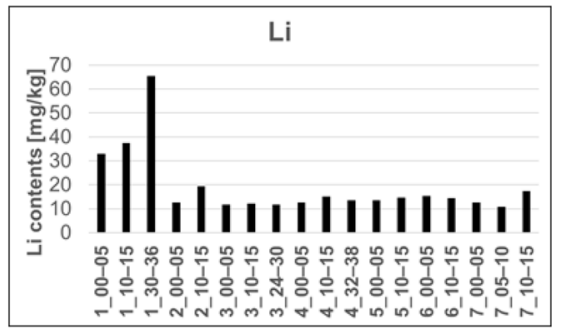

(b) Group 1

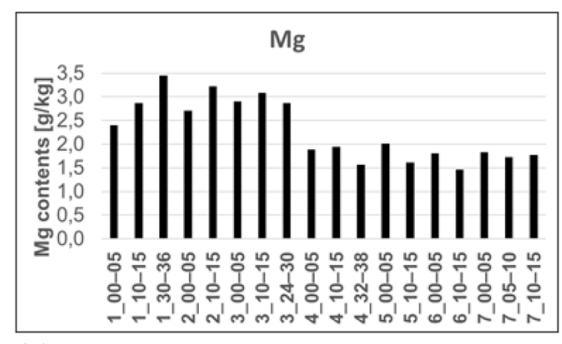

(c) Group 2

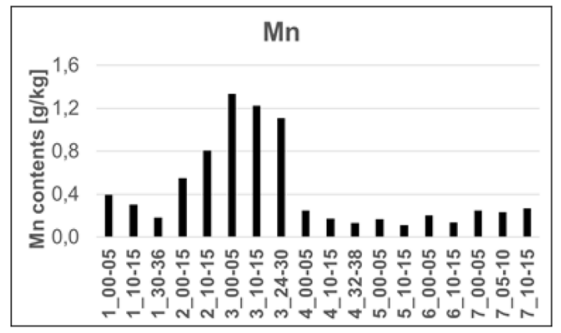

(d) Group 3

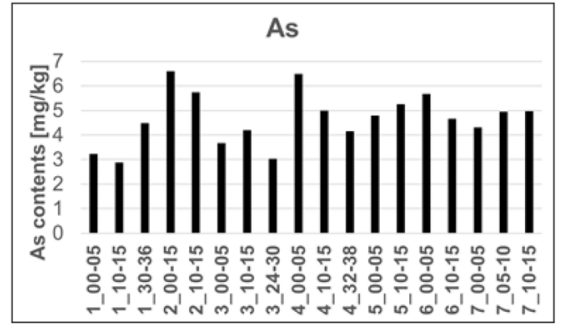

(e) Group 4

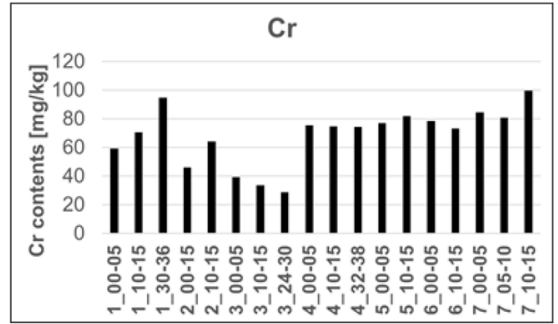

(f) Group 5

Fig. 3 a Cluster analysis of the element distribution patterns using Ward's method with the squared Euclidean distance and z-transformed concentration values; b-f Graphical representation of the characteristic element distribution patterns for each of the five groups

$\mathrm{Al}$ contents differ a lot from our results (8-12 times more $\mathrm{Al}$ in SP 1 (our study) than at the SP XIV near Nyandorera-SP closest to the lake (Mwamburi 2003)). This disagreement is most likely caused by the digestion method (30 min at $60{ }^{\circ} \mathrm{C}$ in aqua regia on a hotplate). Studies show that lower $\mathrm{Al}$ recoveries for hotplate digestions already become visible at hotplate conditions of $3 \mathrm{~h}$ at $110{ }^{\circ} \mathrm{C}(40 \%$ less in comparison to the applied microwave digestion) (Cheng and Ma 2001). This effect rather worsens with decreasing temperature and digestion time; therefore, comparisons are not possible for parameters analysed by different methods, i.e. aluminium and trace elements. LOI seems comparable between SP 1 (our study) and SP XIV, though (4.2-10\% (Mwamburi 2003) vs. 4.2-17.6\% (this study)). Group 3 (Mn, distance, $\mathrm{Ba}, \mathrm{Cd}, \mathrm{TP}$ ) describes the influence of the distance between the shore and the sampling point, containing elements with an enrichment visible in sampling points 2 and 3, with Mn correlating most with it. This is the result of the geochemical focussing of Mn, which shifts bioavailable $\mathrm{Mn}^{2+}$ from nearshore towards deeper areas (Schaller and Wehrli 1997). The effects of that are also visible in the Group speciation results (next section). Group 4 (Ca, Sr, Se, 
As, $\mathrm{Pb}, \mathrm{LOI}$ ) combines the elements with seemingly no visible pattern in their distribution over the different sampling points. Group 5 (V, Cr, Mo, Cu, Ti) includes elements showing an enrichment in sampling points 4-7. The fact, that those elements mostly have an anthropogenic background (for example steel) matches the locality of sampling points 4-7 with their urban surroundings. The cluster analysis of the element patterns explains the apparent split of sampling points 1-3 and sampling points 4-7. In addition, it reinforces the hypothesis that the difference in land use and the extent of urbanisation in areas near the sampling points play an important role on the sediment quality. The results of the factor analysis given in Table 4 can be used to clearly contrast the sampling points located at the shoreline with sampling points 2 and 3 , as stated by factor 1 . The distance to the shore correlates positively with the element contents of Mn (group 3), whereas Cr, Mo and V contents (group 2) are correlating negatively with it. Factor 1 has a strong positive effect on sampling points 2 and 3 and a moderate to strong negative effect on sampling points 4-7 and the lowest sample of SP 1. Excluded from this is the sample 4_00-05, as already observed in the cluster analysis of the samples. Factor 2 mainly affects SP 1, correlating positively with $\mathrm{Ni}, \mathrm{Li}, \mathrm{Al}, \mathrm{Co}, \mathrm{Be}, \mathrm{Mg}$, and $\mathrm{Rb}$ contents (groups 1 and 2 ) and negatively with the LOI. It emphasises the impact of the rivers Sio and Nzoia on the sediment composition of SP1 and the change of the riverine sediment composition due to increasing degradation of the catchment areas, since the factor loadings for sample 1_30-36 is about three times higher than the ones of the other samples of SP 1. Factor 3 which describes only $15.6 \%$ of the variance with significant loadings of only As and $\mathrm{Sr}$ could not have been assigned to a specific cause.

\section{Statistical analyses of speciation results (BCR procedure)}

The FP and SC of each of the studied elements resulting from the BCR extraction is indicated in the supplementary information (Tables S5 and S6). When using the data obtained by the BCR extraction for cluster analysis, both dendrograms of summed contents and fraction percentages show a split of sampling points $1-3$ and sampling points 4-7 (Fig. S1). The former indicates a good agreement between the results of the pseudo-total digestion and the sequential extraction. The latter might be caused by differences in the binding behaviour of the two sampling point groups. The binding behaviour of the elements was assessed by cluster analysis trying to find regional differences between the sampling points. Furthermore, the results for the "priority" trace elements ( $\mathrm{As}, \mathrm{Cd}, \mathrm{Cr}, \mathrm{Cr}, \mathrm{Ni}, \mathrm{Pb}$, and $\mathrm{Zn}$ ) will be compared with the literature (Bódog et al. 1997; Cao et al. 2015; Cappuyns et al. 2006; Cuong and Obbard 2006; Dundar et al. 2012; Gomez Ariza et al. 2000; Tokalioğlu et al. 2000; Zhigang 2008). Figure 4a shows the dendrogram resulting from the cluster analysis with the data containing the
Table 4 Factor loadings (a) and scores (b) resulting from the factor analysis using the normalised data containing pseudo-total element contents, TP, LOI and the closest distance between shore and the SP

\begin{tabular}{|c|c|c|c|c|c|c|c|}
\hline (a) & F1 & $\mathrm{F} 2$ & F3 & (b) & F1 & $\mathrm{F} 2$ & F3 \\
\hline Mn & 0.92 & & & 1_00-05 & 0.22 & 0.68 & -1.25 \\
\hline Distance & 0.91 & & & 1_10-15 & -0.06 & 1.39 & -1.22 \\
\hline V & -0.89 & & & 1_30-36 & -0.68 & 3.15 & -0.18 \\
\hline $\mathrm{Cr}$ & -0.96 & & & 2_00-05 & 0.80 & 0.02 & 1.20 \\
\hline Mo & -0.85 & & & $2 \_10-15$ & 0.70 & 0.77 & 1.74 \\
\hline $\mathrm{Li}$ & & 0.92 & & 3_00-05 & 1.98 & -0.11 & 0.15 \\
\hline $\mathrm{Be}$ & & 0.84 & & 3_10-15 & 1.48 & 0.02 & -0.05 \\
\hline $\mathrm{Mg}$ & & 0.71 & & 3_24-30 & 2.00 & -0.48 & -0.71 \\
\hline $\mathrm{Al}$ & & 0.86 & & 4_00-05 & -0.17 & -0.66 & 1.75 \\
\hline Co & & 0.79 & & $4 \_10-15$ & -0.40 & -0.62 & -0.43 \\
\hline $\mathrm{Ni}$ & & 0.83 & & $4 \_32-38$ & -0.40 & -0.71 & -1.31 \\
\hline $\mathrm{Rb}$ & & 0.84 & & 5_00-05 & -0.38 & -0.94 & -0.17 \\
\hline LOI & & -0.84 & & $5 \_10-15$ & -0.74 & -0.89 & -0.94 \\
\hline As & & & 0.70 & 6_00-05 & -0.57 & -0.54 & 0.16 \\
\hline \multirow[t]{4}{*}{$\mathrm{Sr}$} & & & 0.81 & $6 \_10-15$ & -0.54 & -0.68 & -1.08 \\
\hline & & & & 7_00-05 & -1.01 & -0.13 & 0.73 \\
\hline & & & & 7_05-10 & -0.87 & -0.28 & 0.74 \\
\hline & & & & 7_10-15 & -1.35 & 0.03 & 0.88 \\
\hline
\end{tabular}

Only elements showing a factor loading of 0.7 or higher (absolute value) are listed, since no significant correlation occurs below that $(\mathrm{F} 1: 29.5 \%$ of total variance; $\mathrm{F} 2: 28.6 \%$ of total variance; $\mathrm{F} 3: 15.6 \%$ of total variance). A complete indication of the results is listed in the supplementary information (Table S4) 


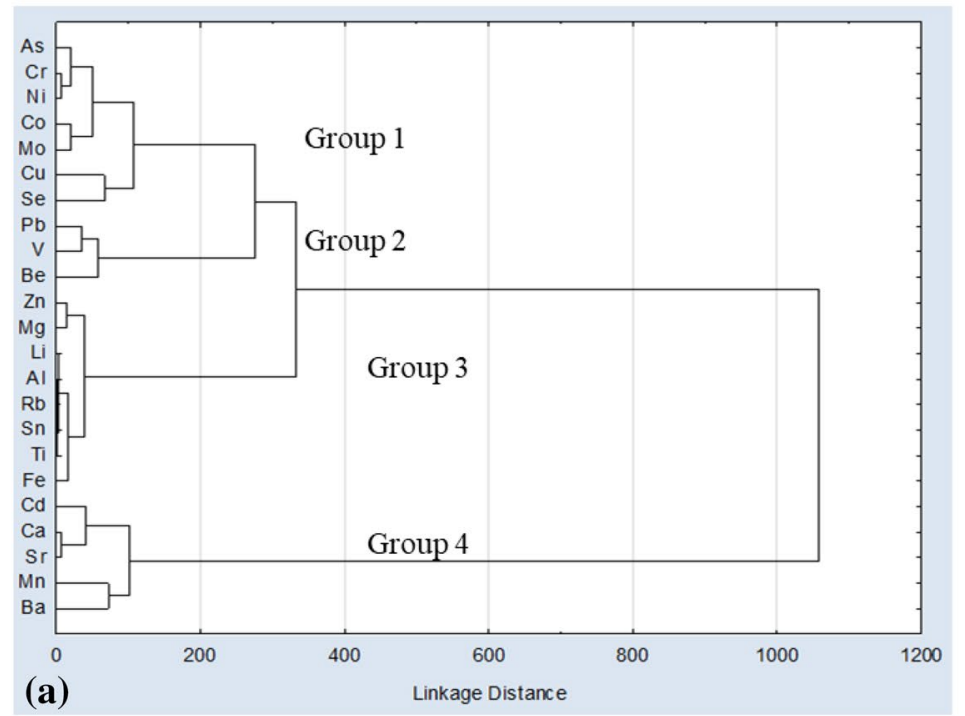

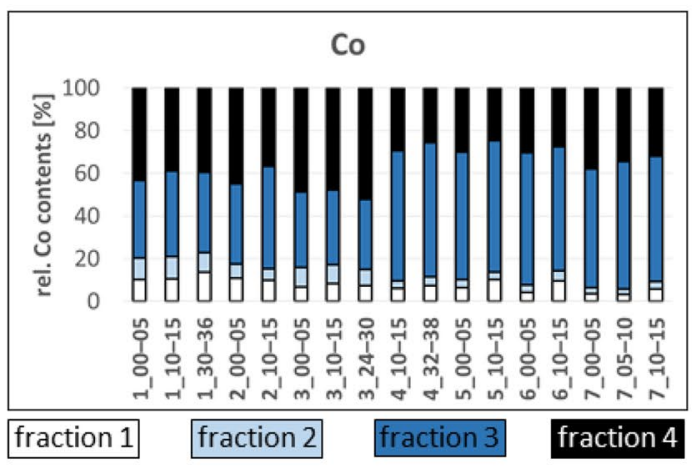

(b) Group 1

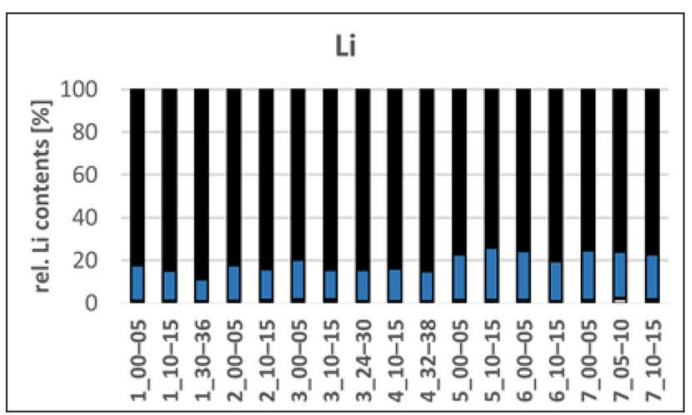

(d) Group 3

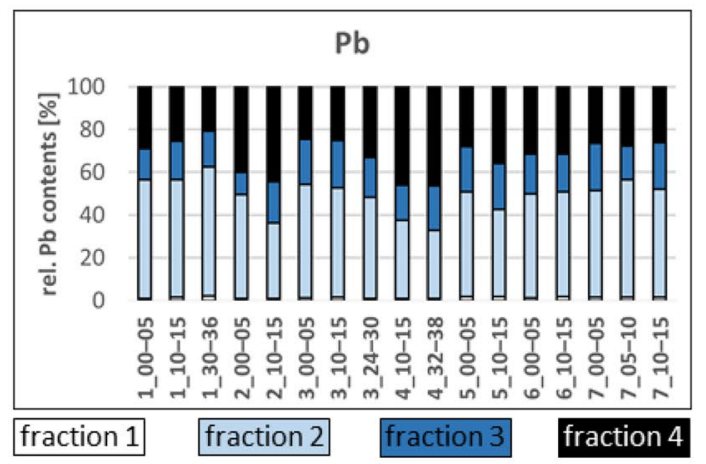

(c) Group 2

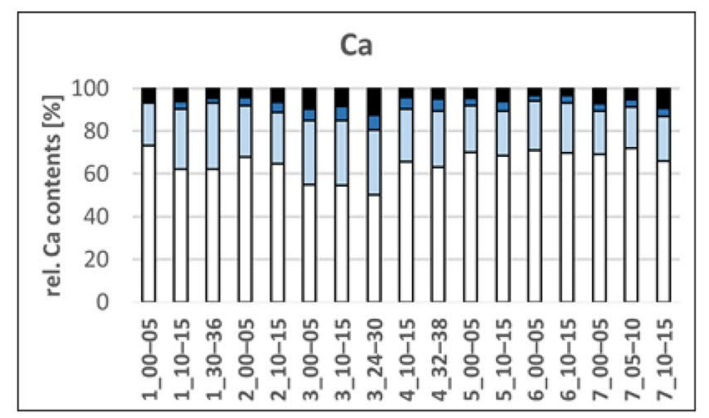

(e) Group 4

Fig. 4 a Cluster analysis of the element's binding behaviour using Ward's method with the squared Euclidean distance and $z$-transformed concentration values; $\mathbf{b}-\mathbf{e}$ graphical representation of the characteristic binding behaviours for each of the four groups

fraction percentages. For each element group with similar binding behaviour (named BCR-group for clarity), an example is given in a chart next to the dendrogram (Fig. 4b-e). BCR-group 1 ( $\mathrm{As}, \mathrm{Cr}, \mathrm{Ni}, \mathrm{Co}, \mathrm{Mo}, \mathrm{Cu}$, and $\mathrm{Se}$ ) includes elements bound mainly in the third and fourth fraction in equal parts, with the exceptions of $\mathrm{Cu}$ (bound in the 2 nd fraction with 20-30\%) and $\mathrm{Se}$ (share of 3rd fraction equals 90\%). Comparing the results to the literature, As arsenic shows the expected behaviour, as it is usually found as an arsenate impurity in geogenic apatite (Moore and Ramamoorthy 1984) and precipitates as sulphide, incorporated with Fe (Chakraborti et al. 2001). Nickel has the typical 
binding percentages for lake sediments. Copper and $\mathrm{Cr}$ exhibit a varying binding behaviour probably depending on the amount of organic matter present in the water. There seem to be a weak correlation between the FP of the third fraction and the LOI in the samples. The elements of BCRgroup $2(\mathrm{~Pb}, \mathrm{~V}, \mathrm{Be})$ are all bioavailable with a percentage of ca. 50\%. Whereas $\mathrm{Pb}$ and $\mathrm{V}$ are mainly bound to the second fraction, $\mathrm{Be}$ is as well found in the first fraction of the BCR extraction. No comparable results for the binding behaviour of $\mathrm{Pb}$ were found in the literature. Since all samples share the same characteristics for $\mathrm{Pb}$, it can be assumed that regional specificities of (northeastern) Lake Victoria are the reason for that. BCR-group $3(\mathrm{Zn}, \mathrm{Mg}, \mathrm{Zr}, \mathrm{Li}, \mathrm{Al}, \mathrm{Rb}, \mathrm{Sn}$, $\mathrm{Ti}, \mathrm{K}$, and $\mathrm{Fe}$ ) consists of elements with low potential of damaging the aquatic ecosystem of Lake Victoria, since the percentage of the fourth fraction lies between 80 and $90 \%$, except for $\mathrm{Zn}, \mathrm{Mg}, \mathrm{K}$ and $\mathrm{Fe}$ (share of 4 th fraction is around $60 \%)$. $\mathrm{Zn}$ has a slightly elevated percentage of the first fraction in the samples of sampling points 4-7 which, according to literature, might imply an increased anthropogenic input of $\mathrm{Zn}$ into the lake. This is not reflected in the pseudo-total $\mathrm{Zn}$ contents of the sediments, rather exhibiting an enrichment of $\mathrm{Zn}$ in sampling points $1-3$, though. However, it is possible, that higher anthropogenic inputs of $\mathrm{Zn}$ at sampling points 4-7 are just overlapped by the natural regiospecific enrichment of $\mathrm{Zn}$ at SP 1-3. BCR-group 4 (Cd, Ba, Mn, Ca, $\mathrm{Sr}$ ) contains elements with a high bioavailable percentage $(80 \%)$. For $\mathrm{Mn}$, this partly applies, since the high bioavailability is only present in the samples of SP 2 and 3. For coastal sediments, the binding behaviour of Mn equals the third BCR-group. This is due to the geochemical focussing of $\mathrm{Mn}$, which causes a migration of bioavailable $\mathrm{Mn}^{2+}$ into the deeper parts of the lake (Schaller and Wehrli 1997). The enrichment of Mn in SP 2 and 3 supports this hypothesis. Cadmium is known to be a bioavailable element. However, with no noteworthy pseudo-total Cd contents in the sediments, this fact is not alarming. As in the case of the pseudototal contents, the results of the factor analysis regarding the FP of the BCR extraction (Table 5) can be used to verify the cluster analysis. Both statistical methods are in good accordance with each other. BCR-factor 1 contains the elements of
BCR-group 3, which show a clear preference of being bound in the fourth fraction of the BCR extraction. In addition, $\mathrm{Cr}$ and $\mathrm{Ni}$ changed sides from former BCR-group 1. BCRfactor 2 represents BCR-groups 1 (positive correlation) and 4 (negative correlation). Copper from BCR-group 1 could not have been clearly assigned to any factor, caused by its unique behaviour of being bound in the second fraction significantly. Nevertheless, it shows a tendency towards BCRfactor 2 as well (factor loading 0.65). The fact, that $\mathrm{Cr}$ and $\mathrm{Ni}$ are not found in BCR-factor 2 might be caused by their weaker preference to bind in the third fraction. BCR-group 4 represents the opposite of BCR-group 1, hardly being bound in the third fraction and exhibiting a significant bioavailability. Calcium and Mn of BCR-group 4 show no significant correlation with BCR-factor 2, but a tendency towards that is present as well (factor loading -0.68 , respectively, -0.65 ). Lastly, BCR-factor 3 describes the elements of BCR-group 2 , which prefer to bind in the second fraction. The low factor score for the first fraction matches $\mathrm{Pb}$ and $\mathrm{V}$, but does not correspond to Be which shows a fraction percentage of the first fraction equal to that of the second fraction. That difference might have caused the lower factor loading of $\mathrm{Be}$ for BCR-factor $3(0.71$ compared to $0.8(\mathrm{~V})$ and $0.93(\mathrm{~Pb})$ ).

\section{Summarised discussion}

Comparing the pseudo-total contents of trace elements in sediments of the northeastern part of Lake Victoria with other regions of the lake, lower levels of $\mathrm{Zn}$ and $\mathrm{Cd}$ and higher levels of $\mathrm{Ni}, \mathrm{Cu}$ and $\mathrm{Cr}$ become apparent in the investigated area of this study. By the application of $I_{\text {geo }}$, it was possible to identify SP 3 as the least and SP 7 as the most contaminated sampling point, drawing a connection between the distance to the shore/urbanity and trace-element contamination of the sediments. At SP 7, two main sources for $\mathrm{Cr}$ and $\mathrm{Cu}$ pollution were found-the leather industry and a $\mathrm{Cu}$ smelter, which was closed in 1982. Untreated wastewaters from the $\mathrm{Cu}$ smelter were directly discharged into Masese Wetland and led to a massive contamination of its soils, which influences on the sediment composition of Lake Victoria near Jinja, being intensified by a waste dump having

Table 5 Factor loadings (a) and scores (b) resulting from the factor analysis using the normalised data containing the fraction percentages in each fraction of all of the studied elements

\begin{tabular}{|c|c|c|c|c|c|c|c|}
\hline (a) & $\mathrm{F} 1$ & $\mathrm{~F} 2$ & F3 & (b) & $\mathrm{F} 1$ & $\mathrm{~F} 2$ & F3 \\
\hline$\geq 0.7$ & $\begin{array}{l}\mathrm{Cr}, \mathrm{Ni}, \mathrm{Zn}, \mathrm{Li}, \mathrm{Al}, \mathrm{Mg}, \\
\quad \mathrm{Ti}, \mathrm{Fe}, \mathrm{Rb}, \mathrm{Sn}\end{array}$ & $\mathrm{Co}, \mathrm{Se}, \mathrm{Mo}, \mathrm{As}$ & $\mathrm{Pb}, \mathrm{Be}, \mathrm{V}$ & $\begin{array}{l}\text { Fraction } 1 \\
\text { Fraction } 2\end{array}$ & $\begin{array}{l}-0.31 \pm 0.2 \\
-0.76 \pm 0.16\end{array}$ & $\begin{array}{l}-0.81 \pm 0.31 \\
-0.81 \pm 0.25\end{array}$ & $\begin{array}{l}-1.44 \pm 0.32 \\
1.25 \pm 0.62\end{array}$ \\
\hline$\leq-0.7$ & & $\mathrm{Cd}, \mathrm{Ba}, \mathrm{Sr}$ & & $\begin{array}{l}\text { Fraction } 3 \\
\text { Fraction } 4\end{array}$ & $\begin{array}{l}-0.62 \pm 0.17 \\
1.69 \pm 0.26\end{array}$ & $\begin{array}{l}1.57 \pm 0.4 \\
0.06 \pm 0.58\end{array}$ & $\begin{array}{l}0.1 \pm 0.43 \\
0.25 \pm 0.43\end{array}$ \\
\hline
\end{tabular}

Only elements showing a factor loading of 0.7 or higher (absolute value) are listed, since no significant correlation occurs below that (F1: $57.7 \%$ of total variance; F2: $20.9 \%$ of total variance; F3: $11.7 \%$ of total variance). The factor scores of the samples are similar within one fraction, so only the mean $\pm 95 \%$ CI is indicated. Full indication of the individual samples and fractions as well as the factor loadings of each element are shown in the supplementary information (Table S7) 
been left on the ground of the former $\mathrm{Cu}$ smelter, can still be seen today. As the $\mathrm{Cu}$ content exceeds the LAWA criteria, the waste dump causes potential $\mathrm{Cu}$ contamination to the aquatic ecosystem. Apart from that, according to LAWA, no major trace-element contamination becomes apparent in the sediments of northeastern Lake Victoria. However, some changes in the element distribution are recognisable that might be caused by anthropogenic influences. The element patterns suggests an enrichment of $\mathrm{Cr}, \mathrm{V}$ and $\mathrm{Mo}(+\mathrm{Cu}$ and $\mathrm{Ti}$ ) in the coastal sediments near urban areas (sampling points 4-7). Addressed elements are altogether mainly distributed by anthropogenic emissions. SP 1 near the estuary of river Nzoia demonstrates the change of land use taking place in the catchment area of the lake and its influence on the lake's sediment composition. Increased agricultural area and decreased forest cover most likely led to enhanced soil erosion causing a higher input of organic matter into Lake Victoria. The bloom of the water hyacinth might have contributed to that as well.

\section{Conclusion}

Most trace-element loads are harmless and no strong increase in trace-element inputs over time was observed. However, anthropogenic induced changes in the sediment composition of coastal areas with urban influences were apparent as shown by elevated levels of trace elements with an anthropogenic background $(\mathrm{Cr}, \mathrm{V}, \mathrm{Mo}, \mathrm{Cu}$ and $\mathrm{Ti}$ ).

The strong influence of river Nzoia on the sediment composition of SP 1 demonstrates that the whole catchment area is responsible for ensuring a healthy aquatic ecosystem in Lake Victoria. The city of Jinja plays an important role since it is located near the outflow of Lake Victoria (River Nile) and influences the water quality even beyond the borders of the lake. High trace-element inputs into Lake Victoria might affect aquatic cohabitation of the River Nile. High inputs of $\mathrm{Cu}$ and $\mathrm{Cr}$ by industrial wastewaters have already been reported in the past. Since $\mathrm{Cu}$ and $\mathrm{Cr}$ contents are lower in the upper sediment layers, the situation has slightly been improved though.

Further studies should extend the investigated area. It would be interesting to see, if the connections between land use changes and the sediment composition found for River Nzoia also apply to River Kagera in the north-western Lake Victoria. In addition, a closer look should be taken closer to Kampala. There, the city's influence on the ecosystem might be more distinctive and better to investigate than at SP 4 of this study.
Supplementary Information The online version contains supplementary material available at https://doi.org/10.1007/s12665-021-09554-1.

Acknowledgements We acknowledge the Director of National Fisheries Resources Research Institute (NaFIRRI) Anthony Taabu Munyaho for facilitating the cruise on Lake Victoria. We thank the crew of the NaFIRRI ship (R. V. Hammerkop): Edward Mutatura, Stepphen Opolot-Oula, Prosper Musiiwe, Simpson Tweheyo, Sunday Girigora, Charles Balise, Madoi Muhammed, and Hajji Mukose Salim for navigation and their immense support during sampling. Many thanks go to: Stephen Mulinda of Makerere University (sampling, sample preparation and all on-board measurements) and Stephen Magezi of NaFIRRI who coordinated our stay in Jinja and helped us with sampling and profiling on board. We acknowledge the support of the World Water Quality Alliance (WWQA), its pilot Use Cases in Africa and activities in the Lake Victoria region, supported by the Swiss Confederation through the United Nations Environment Programme (UNEP). The trip was additionally supported by Grant number I-2-W-4880-2 from the International Foundation for Science (IFS) in conjunction with the Organisation for the Prohibition of Chemical Weapons (OPCW). We thank the Friedrich Schiller University, whose cooperation with the Helmholtz Centre for Environmental Research enabled the Master thesis by Nils Ribbe that finally led to this paper. We also thank Michael Herzog, Andrea Hoff, Christina Hoffmeister, Daniele Frascareli and Charlotte Tuerpe who helped with sample analysis.

Author contributions All the authors excluding Tallent Dadi and Nils Ribbe contributed to the study conception and design. Sampling, sediment preparation, data collection and analysis were performed mainly by Kenneth Arinaitwe, Tallent Dadi and Nils Ribbe. The judge- and assessment has been done by all the authors. The manuscript was written by Nils Ribbe and Wolf von Tümpling with support of the other authors in revision of the manuscript. All the authors read and approved the final manuscript.

Funding Open Access funding enabled and organized by Projekt DEAL. The trip was financially supported by Grant number I-2-W4880-2 from the International Foundation for Science (IFS) in conjunction with the Organisation for the Prohibition of Chemical Weapons (OPCW). This paper originates from the Master thesis conducted by Nils Ribbe at the Helmholtz Centre for Environmental Research, at that time having been enrolled as Master student at Friedrich Schiller University Jena (Department of Inorganic and Analytical Chemistry, Lessingstraße 8, 07743 Jena, Germany).

Availability of data and material All data are given in the supplementary material of this paper.

Code availability Not applicable.

\section{Declarations}

Conflict of interest Finally, the authors declare that they have no conflict of interest.

Open Access This article is licensed under a Creative Commons Attribution 4.0 International License, which permits use, sharing, adaptation, distribution and reproduction in any medium or format, as long as you give appropriate credit to the original author(s) and the source, provide a link to the Creative Commons licence, and indicate if changes were made. The images or other third party material in this article are included in the article's Creative Commons licence, unless indicated 
otherwise in a credit line to the material. If material is not included in the article's Creative Commons licence and your intended use is not permitted by statutory regulation or exceeds the permitted use, you will need to obtain permission directly from the copyright holder. To view a copy of this licence, visit http://creativecommons.org/licenses/by/4.0/.

\section{References}

Bódog I, Polyák K, Hlavay J (1997) Determination of heavy metals in lake and river sediments by selective leaching. Int J Environ Anal Chem 66:79-94. https://doi.org/10.1080/03067319708028353

Cao L et al (2015) Multivariate analyses and evaluation of heavy metals by chemometric BCR sequential extraction method in surface sediments from Lingdingyang Bay, South China. Sustainability 7:4938-4951. https://doi.org/10.3390/su7054938

Cappuyns V, Swennen R, Niclaes M (2006) Application of the BCR sequential extraction scheme to dredged pond sediments contaminated by $\mathrm{Pb}-\mathrm{Zn}$ mining: a combined geochemical and mineralogical approach. J Geochem Explor 93:78-90. https://doi.org/10. 1016/j.gexplo.2006.10.001

Chakraborti D et al (2001) Characterization of arsenic-bearing sediments in the Gangetic delta of West Bengal, India. In: Chappell WR, Abernathy CO, Calderon RL (eds) Arsenic exposure and health effects IV. Elsevier Science Ltd, Oxford, pp 27-52

Cheng M, Ma LQ (2001) Comparison of three aqua regia digestion methods for twenty Florida soils. Soil Sci Soc Am J 65:491-495. https://doi.org/10.2136/sssaj2001.652491x

Cuong DT, Obbard JP (2006) Metal speciation in coastal marine sediments from Singapore using a modified BCR-sequential extraction procedure. Appl Geochem 21:1335-1346. https://doi.org/10. 1016/j.apgeochem.2006.05.001

de la Paix MJ, Lanhai L, Xi C, Ahmed S, Varenyam A (2013) Soil degradation and atered flood risk as a consequence of deforestation. Land Degrad Dev 24:478-485. https://doi.org/10.1002/ldr.1147

Dundar MS, Altundag H, Eyupoglu V, Keskin SC, Tutunoglu C (2012) Determination of heavy metals in lower Sakarya river sediments using a BCR-sequential extraction procedure. Environ Monit Assess 84:33-41. https://doi.org/10.1007/s10661-011-1944-7

Duruibe JO, Ogwuegbu MOC, Egwurugwu JN (2007) Heavy metal pollution and human biotoxic effects. Int J Phys Sci 2:112-118

Filgueiras AV, Lavilla I, Bendicho C (2002) Chemical sequential extraction for metal partitioning in environmental solid samples. J Environ Monit 4:823-857. https://doi.org/10.1039/B207574C

Förstner U (1985) Chemical forms and reactivities of metals in sediments. In: Leschber R, Davis RD, L'Hermite P (eds) Chemical methods for assessing bio-available metals in sludges and soils. Elsevier Apllied Science Publishers, London, pp 1-31

Fuhrimann S, Stalder M, Winkler MS, Niwagaba CB, Babu M, Masaba G, Kabatereine NB, Halage AA, Schneeberger PHH, Utzinger J, Cissé G (2015) Microbial and chemical contamination of water, sediment and soil in the Nakivubo wetland area in Kampala, Uganda. Environ Monit Assess 187:475-489. https:// doi.org/10.1007/s10661-015-4689-x

Githui F, Mutua F, Bauwens W (2009) Estimating the impacts of land-cover change on runoff using the soil and water assessment tool (SWAT): case study of Nzoia catchment, Kenya. Hydrol Sci J 54:899-908. https://doi.org/10.1623/hysj.54.5.899

Gomez Ariza JL, Giraldez I, Sanchez-Rodas D, Morales E (2000) Comparison of the feasibility of three extraction procedures for trace metal partitioning in sediments from south-west Spain. Sci Total Environ 246:271-283. https://doi.org/10.1016/S00489697(99)00468-4
Google (n.d.) Map of Lake Victoria with a detailed view on the northeastern part of the lake. https://www.google.com/ maps/place/Victoriasee/@-1.2660742,32.1034739,8z/data= !3m1!4b1!4m5!3m4!1s0x19d18e2143b96ce1:0x5df3e171f5566 538 !8m2!3d-0.7557754!4d33.438353. Accessed 8 June 2020

Hecky RE, Mugidde R, Ramlal PS, Talbot MR, Kling GW (2010) Multiple stressors cause rapid ecosystem change in Lake Victoria. Freshw Biol 55:19-42. https://doi.org/10.1111/j.1365-2427. 2009.02374.x

Hongo T, Obutu LKM, Merie F, Group DS (2008) Bunyala District-2008 short rains assessment report. https://reliefweb.int/ sites/reliefweb.int/files/resources/4504FAC68208BA444925 7411000ADC4F-Full_Report.pdf. Accessed 08 June 2020

Jenne EA, Luoma SN (1975) Forms of trace elements in soils, sediments, and associated waters: an overview of their determination and biological availability. In: Drucker H, Wildung RE (eds) Biological implications of metals in the environment, Richland, Washington. Technical Information Center, Energy Research and Development Administration, pp 110-143

Kayombo S, Jorgensen SE (2005) Lake Victoria-experience and lessons learned brief. IW:LEARN. https://iwlearn.net/resol veuid/b4a50abbd2c57c3a8ce61a368790829a. Accessed 08 June 2020

Krüger F, Aulinger A, Berger H, Stachel B (2000) Multi-element analysis of water samples of River Elbe and selected tributaries: sampling along a longitudinal profile of September 1997 (in German). Arbeitsgemeinschaft für die Reinhaltung der Elbe, Potsdam

Lake Victoria Basin Commission and GRID-Arendal (2017) Lake Victoria Basin: atlas of our changing environment. Lake Victoria Basin Commission and GRID-Arendal, Kisumu

LAWA-working groups "Zielvorgaben" und "Qualitative Hydrologie von Fließgewässern" (1998) Assessment of water quality of river waters in the federal republic of Germany-chemical qualification of water quality (in German). Länderarbeitsgemeinschaft Wasser (LAWA), Berlin

Machiwa JF (2010) Nature of suspended particulate matter and concentrations of heavy metals in sediment in the southern part of Lake Victoria, East Africa. Afr J Aquat Sci 35:95-101. https://doi.org/ 10.2989/16085914.2010.466592

Margui E, Salvadó V, Queralt I, Hidalgo M (2004) Comparison of three-stage sequential extraction and toxicity characteristic leaching tests to evaluate metal mobility in mining wastes. Anal Chim Acta 524:151-159. https://doi.org/10.1016/j.aca.2004.05.043

Mbabazi J, Kwetegyeka J, Ntale M, Wasswa J (2010) Ineffectiveness of Nakivubo wetland in filtering out heavy metals from untreated Kampala urban effluent prior to discharge into Lake Victoria. Afr J Agric Res 5:3431-3439. https://doi.org/10.5897/AJAR10.013

Moore JW, Ramamoorthy S (1984) Heavy metals in natural waters: apllied monitoring and impact assessment. Springer, New York. https://doi.org/10.1007/978-1-4612-5210-8

Müller G (1979) Heavy metals in sediments of River Rhine-changes since 1971 (in German). Umschau 24:778-783

Mwamburi J (2003) Variations in trace elements in bottom sediments of major rivers in Lake Victoria's basin, Kenya. Lake Reserve Res Manag 8:5-13. https://doi.org/10.1046/j.1440-1770.2003.00212.x

Nabulo G, Oryem Origa H, Nasinyama GW, Cole D (2008) Assessment of $\mathrm{Zn}, \mathrm{Cu}, \mathrm{Pb}$ and $\mathrm{Ni}$ contamination in wetland soils and plants in the Lake Victoria basin. Int J Sci Technol 5:65-74. https://doi. org/10.1007/BF03325998

NewVision Reporter (2013) Ghost of copper mining still haunts environment. Vision Group Resource Centre. https://www.newvision. co.ug/news/1319514/ghost-copper-mining-haunts-environment. Accessed 08 June 2020

Ngure V, Davies T, Kinuthia G, Sitati N, Shisia S, Oyoo-Okoth E (2014) Concentration levels of potentially harmful elements 
fromgold mining in Lake Victoria Region, Kenya: environmental and health implications. J Geochem Explor 144:511-516. https:// doi.org/10.1016/j.gexplo.2014.04.004

Ochiel GRS, Njoka SW (2005) Biological control and monitoring of water hyacinth, Eichhornia crassipes, Marts. Solms-Laubach (Liliales: Ponteridiaceae) during the post-resurgence period in Lake Victoria basin, Kenya. Kenya Agricultural Research Institute, LVEMP Water Hyacinth Control Component National Fibre Research Centre. http://repository.eac.int/handle/11671/733? locale-attribute $=$ en. Accessed 08 June 2020

Oguttu HW, Bugenyi FWB, Leuenberger H, Wolf M, Bachofen R (2008) Pollution menacing Lake Victoria: quantification of point sources around Jinja Town, Uganda. Water SA 34:89-98. https:// doi.org/10.4314/wsa.v34i1.180865

Okungu J, Opango P (2002) Pollution loads into Lake Victoria from the Kenyan catchment. Ministry of Environment and Natural Resources (LVEMP), Kisumu

Onywere SM, Getenga ZM, Baraza W, Twesigye CK, Mwakalila SS, Nakiranda JK (2007) Intensification of agriculture as the driving force in the degradation of Nzoia River Basin: the challenges of watershed management. Paper presented at the Lake Abaya Research Symposium 2007 (LARS 2007), Arba Minch, Ethiopia, 07.-11.05.2020

Outa JO, Kowenje CO, Plessl C, Jirsa F (2020) Distribution of arsenic, silver, cadmium, lead and other trace elements in water, sediment and macrophytes in the Kenyan part of Lake Victoria: spatial, temporal and bioindicative aspects. Environ Sci Pollut Res 27:14851498. https://doi.org/10.1007/s11356-019-06525-9

Peng J-F, Song Y-H, Yuan P, Cui X-Y, Qiu G-L (2009) The remediation of heavy metals contaminated sediment. J Hazard Mater 161:633-640. https://doi.org/10.1016/j.jhazmat.2008.04.061

Piccolo A (1996) Humus and soil conservation. In: Piccolo A (ed) Humic substances in terrestrial ecosystems. Elsevier B.V., pp 225-264. https://doi.org/10.1016/B978-044481516-3/50006-2

Ramlal PS, Bugenyi FWB, Kling GW, Nriagu JO, Rudd JWM, Campbell LM (2003) Mercury Concentrations in Water, Sediment, and Biota from Lake Victoria, East Africa. J Great Lakes Res 29:283-291

Rauret G (1998) Extraction procedures for the determination of heavy metals in contaminated soil and sediment. Talanta 46:449-455. https://doi.org/10.1016/S0039-9140(97)00406-2

Rauret G, Lopez-Sanchez JF, Lück D, Yli-Halla M, Muntau H, Quevauviller P (2001) The certification of extractable contents (mass fraction) of $\mathrm{Cd}, \mathrm{Cr}, \mathrm{Cu}, \mathrm{Ni}, \mathrm{Pb}$ and $\mathrm{Zn}$ in freshwater sediment following a sequential extraction procedure-BCR-701. European Communities, Luxembourg
Schaller T, Wehrli B (1997) Geochemical-focusing of manganese in lake sediments - an indicator of deep-water oxygen conditions. Aquat Geochem 2:359-378. https://doi.org/10.1007/BF00115977

Sombroek WG, Braun HMH, van der Pouw BJA (1980) Exploratory soil map and agro-climatic zone map of Kenya. Wageningen University and Research E-depot. https://library.wur.nl/WebQuery/ edepot/399397. Accessed 08 June 2020

Tokahoglu S, Kartal S (2006) Multivariate analysis of the data and speciation of heavy metals in street dust samples from the organized industrial district in Kayseri (Turkey). Atmos Environ 40:27972805. https://doi.org/10.1016/j.atmosenv.2006.01.019

Tokalioğlu Ş, Kartal Ş, Elçi L (2000) Determination of heavy metals and their speciation in lake sediments by flame atomic absorption spectrometry after a four-stage sequential extraction procedure. Anal Chim Acta 413:33-40. https://doi.org/10.1016/S00032670(00)00726-1

Uganda Bureau of Statistics (2016) The National Population and Housing Census 2014 - main report. Kampala, Uganda

UNEP (2006) Lake Victoria basin outlook: environment and development. Nairobi

URN Reporter (2009) Austrian company starts copper trials at Jinja Smelter. Uganda Radio Network. https://ugandaradionetwork. net/story/austrian-company-starts-copper-trials-at-jinja-smelter. Accessed 08 June 2020

Verschuren D et al (2002) History and timing of human impact on Lake Victoria, East Africa. Proc R Soc B 269:289-294. https://doi.org/ 10.1098/rspb.2001.1850

von Tümpling W, Scheibe N, Einax JW (2013) Extended sediment quality rating for trace elements in urban waters-case study Klinke, Germany. Clean (Weinh) 41:565-573. https://doi.org/10. 1002/clen.201100032

Wanda FM, Namukose M, Matuha M (2016) Water hyacinth hotspots in the Ugandan waters of Lake Victoria in 1994-2012: implications for management. Afr J Aquat Sci 40:101-106. https://doi. org/10.2989/16085914.2014.997181

Wong CKC, Yeung HY, Cheung RYH, Yung KKL, Wong MH (2000) Ecotoxicological assessment of persistent organic and heavy metal contamination in Hong Kong Coastal Sediment. Arch Environ Contam Toxicol 38:486-493. https://doi.org/10.1007/s002449910 064

Zhigang Y (2008) Comparison between BCR sequential extraction and geo-accumulation method to evaluate metal mobility in sediments of Dongting Lake, Central China. Chin J Oceanol Limnol 26:14-22. https://doi.org/10.1007/s00343-008-0014-7

Publisher's Note Springer Nature remains neutral with regard to jurisdictional claims in published maps and institutional affiliations. 